\title{
REALIZATION OF LINGUISTIC POLITENESS DURING LEARNING PROCESS
}

\author{
Moh. Docmi Lachmudin ${ }^{1}$, Sayama Malabar ${ }^{2}$, Moh. Karmin Baruadi ${ }^{3}$, Dakia Djou ${ }^{4}$ \\ Universitas Negeri Gorontalo, Gorontalo, Indonesia ${ }^{1234}$ \\ mohamaddocmi@mahasiswa.ung.ac.id ${ }^{1}$
}

\begin{abstract}
This research aims to figure out principles of linguistic politeness during learning process at MAN Model Gorontalo through the realization of linguistic politeness forms. To find meanings of problematic facts existing, the descriptive qualitative approach was applied. Data were collected by employing the observation method with the tapping technique consisting of data recording and writing and advanced technique that was the uninvolved conversation observation technique and analyzed using the qualitative technique with steps as follows: (1) Repetitive data reading, (2) Data identifying, (3) Data coding, (4) Data grouping, (5) Data analyzing, (6) Finding interpreting, and (7) Conclusion drawing. Results of the research show that linguistic politeness forms during learning process are realized by diction use (pronouns, addressing terms, and positive response words) and utterance use (declarative, interrogative, and imperative) with various politeness levels. The research findings point out that linguistic politeness during learning process at MAN Model Gorontalo consists of universal and formal principles.
\end{abstract}

Keywords: linguistic politeness, form, learning process

Numerous experts on linguistics and socio-cultures had conducted research on linguistic politeness, several of which are Goffman (1967), Lakoff (1973), Leech (1983), Brown and Levinson (1987), Sachiko Ide (1989), Fraser (1990), Yueguo Gu (1990). Spencer-Oatey (1992), and BlumKulka (1992). Results of those research brought theories of linguistic politeness majorly cited by other researchers. However, there are pros and contras upon the theories. Pro researchers prove the theories' compatibility to the existing realities; while those who do not support the theories believe that the theories do not suit the realities at all.

Let's take an example from critiques proposed by Spenser-Oatey on politeness theories by Brown and Levinson and Leech. Spencer-Oatey (1992-2000) argues that politeness theories formulated by Brown and Levinson and Leech tended to bias cultures. Spencer-Oatey provides a reason believing that people cannot universally treat the principles of autonomy pointed by their theories since either western or eastern cultures possess its own cultures (see also in Jumanto, 2017:91).

Sachiko Ide also expressed critiques towards the politeness theories by Brown and Levinson and the cooperative principle by Grice. Ide (1989:223-248) gives an argument that the politeness theories by Brown and Levinson cannot define honorific forms commonly used by Japanese people; while Grice's theories are unable to describe linguistic politeness that makes people tend to disobey politeness.

This research aims to investigate the strengths and weaknesses of politeness theory by Leech and cooperative principles by Grice through studies on realization of linguistic politeness forms during learning process at MAN Model Gorontalo as well. The researcher expected to figure out relevant principles of linguistic politeness that might be able to be implemented during learning process at MAN Model Gorontalo.

The researcher selected the topic under the considerations of these following issues. First, both teachers and students of MAN Model Gorontalo came from multicultural ethnics. This is potential in raising conflicts if the communication is not built under the similar politeness principle held by both parties. Second, communication used during learning process has to have educational 
values and sets aims to achieve better learning outputs. Such aims can only be achieved provided the class atmosphere is conducive, indicated by harmonious relationship between teachers and students. Abdurrahman (2012:87) holds the same opinion that both learning motivation and goals can be achieved by such learning atmosphere.

Another consideration was that there was a proof suggesting the fact that language used in communication between teachers and students had violated the principles of linguistic politeness, showed by the following excerpt:

S1 : Bu, kiapa ti Ibu ba pilih jawaban A? (Ma'am, why did you choose the answer A?)

G : Tadi ti Ibu so jelaskan, kamu tidak mangarti? (I have explained it. Do you not understand?)

S1 : Torang mangarti deng yang ti Ibu jelaskan. Tapi beda deng torang dapa selama ini. Baru so mana ini yang butul? (We do understand but it's different from what we have got so far. Which one is correct, then?)

S2 : Iya, Bu! Penjelasan yang ti Ibu kase tadi cuma untuk soal yang menentukan isi tabel bukan simpulan punya.

(Agreed, Ma' am. Your explanation is only suitable for problems of table content, not the problems of conclusion one.)

G : Ini jawaban dari ibu Feronika yang ba kase pelatihan

bedah SKL di MAN Insan Cendekia. (I got the answers from Mrs. Feronika when assisting the output competency standard (Standard Kompetensi Lulusan, SKL) dissection trainings in MAN Insan Cendekia.)

S1 : Torang tidak butuh dari mana ini jawaban. Yang torang butuh alasan kiyapa sampe itu depe jawaban. Kalu torang cocokkan dengan penjelasan Pak Arman, jawaban $C$ yang benar karna yang ditanya simpulan. Simpulan harus mengkafer semua data. Tidak boleh cuma satu. (We do not care where you got the answers from, we need the explanation why you chose the answer. We have consulted to Mr. Arman's explanation and we believe the answer $\mathrm{C}$ is the correct one since the matter here is the conclusion. Conclusion has to cover all data, not only one.)

G : Oh, jadi kamu ba bantah pa ti Ibu. So pintar-pintar berarti

kamu, ee. Kalu bagitu kamu cari guru lain yang lebe kamu dengar (went out of class with anger). (Oh, you argued with me. You think you are clever? Go find another teacher.)

Although previous researchers had conducted research on politeness use of language during learning process as well, there had been no proof that those research results could be implemented at MAN Model Gorontalo due to different cultures. Liu Peng et al. (2014) is one of researchers conducting research on linguistic politeness. Hiring the politeness strategies by Brown and Levinson, during learning process the social distance between teachers and students could be surprisingly decreased, learning activities in class became interesting, and at some points the English learning could be eventually facilitated. Bills (2000:46) also conducted research on the same area and figured out that Ibis' analysis on a conversation among a teacher and two students set goals on being iodisative from several different perspectives regarded as politeness. 
Wijayanto (2013:188-201),in his research proposes that almost all complaints by Indonesian learners seem extremely direct, especially for hearers that are not familiarized with. Students applied four politeness strategies: bald on record, positive politeness, negative politeness, and off record strategies.

Among research explained above, there is no research analyzing or discussing principles of linguistic politeness that might be able to be customized by MAN Model Gorontalo for their learning activities. Hence, the researcher decided that conducting this research by focusing on the realization of linguistic politeness forms during learning process at MAN Model Gorontalo was required. Research focus were divided into two: politeness forms of diction use and politeness forms of utterance use.

The linguistic politeness theory was used to analyze the focus of this research.

\section{Linguistic Politeness in General}

In Indonesian cultures, there are two terms referring to the word 'polite': sopan (wellmannered) and santun (polite). Pramujiono (2011:235) argues that sopan referred to respect given to the hearer; while santun contains euphemistic effect that is to refine utterance that might threaten the hearer's face or self-esteem and hurt his/her feeling. In other words, being sopan means to maintain your behavior and attitude while facing your hearer; while being santun requests you to be polite in speech.

Yule (2006:104-120) believes that politeness is a tool used to raise awareness towards others' faces. The awareness obliges you to acknowledge your hearer so you are able to position him/her in accordance with his/her social status.

Chaer (2010:73) differentiates the terms sopan, santun, and benar (correct). Chaer conveys that being benar and santun is not necessarily being sopan. Chaer (2010:73) adds that an utterance can be regarded as correct by observing the content; a polite utterance can be analyzed from the language used (the language must have the characteristics of politeness); while a well-mannered utterance is related to the topic of utterance, situational contexts of utterance, and social relationship distance between the speaker and the hearer. Hence, someone can be regarded as correct in utterance if the content of his/her utterance is not a lie, polite if his/her utterance is in accordance with the topic being discussed, and well-mannered if his/her utterance is in accordance with the topic being discussed, situation of utterance, and social distance between the speaker and the hearer.

Politeness is one of common social phenomena existing, widely known as a moral code in human communication and social activities.

Brown and Levinson (1987:1) argue that politeness is a complex system to reduce threats targeted to face; whereas Lakoff $(1975: 64)$ views politeness as an idea developed by the society to reduce frictions between intrapersonal communications. Leech (1983:19) holds an opinion that politeness is a strategy to avoid conflicts, measured by the level of attempts taken by the speaker to avoid the conflict (see also Al-Hindawi et al., 2016:1).

There are two theories commonly applied in studies of linguistic politeness: the theory of Cooperative Principles by Grice (hereinafter referred to as $\mathrm{CP}-\mathrm{G}$ ) and the theory of Politeness Principles by Leech (hereinafter referred to as PP-L).

Grice (1975:45) argues in his CP that while the speaker and the hearer are communicating, they want a cooperation upon their communication. Grice $(1975: 45)$ then forms a principle or guidance that might be able to be employed to establish a cooperation in speaking: "Create your contribution in a conversation as being asked by the conversation itself while it is taking place. Create also the destination or direction of conversation that might be accepted by the conversation you are being involved to."

There are four maxims obeyed by both the speaker and hearer to achieve such cooperation: (a) maxim of quantity, (b) maxim of quality, (c) maxim of relation, and (d) maxim of manner. 
However, Leech (2015:121) states that CP is not adequate for achieving such cooperation and formulates PP as the determiner for the cooperation existing. Such act does not indicate that Leech argues PP, proven by his statement:

"If we refuse CP merely due to quantitative matters, we mess the maxims up with statistic norms. A maxim is not a statistic norm. In linguistic universal, there is no one believing that $\mathrm{CP}$ can be implemented in the same method to all linguistic societies."

Leech (2015:121) explains that in a certain situation, people might prefer PP because CP cannot be well hired in exceptional cases without satisfying explanation. It is one of the reasons not to regard $\mathrm{PP}$ as a complementary principle for $\mathrm{CP}$ since in some occasions, $\mathrm{PP}$ is strongly required to save $\mathrm{CP}$.

To reach cooperation in speech, Leech (2015:206-207) proposes six maxims of conversation related to politeness principles: (a) tact maxim, (b) generosity maxim, (c) approbation maxim, (d) modesty maxim, (e) agreement maxim, and (f) sympathy maxim.

\section{Perspectives in Linguistic Politeness}

Linguistic politeness can be analyzed through many perspectives. Fraser (1990:220) figures out that there are at least four perspectives commonly used by researchers: (a) the social norm view, (b) the conversational maxim view, (c) face-saving view, and (d) the conversational contractview (see also Shahrokhi and Bidabadi, 2013:17-27; Rahardi, 2005:38-40).

\section{(a) The Social Norm View}

Fraser (1990:220) argues that the social norm view of politeness is the reflection of politeness understanding historically generated by people, especially those who use English. Held (1992:131153) believes that linguistic politeness in the social norm view emphasizes two factors: (1) Status aware behaviors by showing respects and giving respects to other social communities and (2) Components of morality and decency that are to maintain others' dignity and individualism (Shahrokhi and Bidabadi, 2013:17-27).

The above explanation on the social norm view suggests that a polite utterance is the utterance that obeys the applicable social norms and the indicator is in the compatibility between the utterance and the applicable social norms.

\section{(b) The Conversational Maxim View}

Fraser (1990:222) conveys that the conversational maxim view frequently used in linguistic politeness studies is inspired by Grice in his "Logic and Conversation". Fraser (1990:222) adds that $\mathrm{CP}$ is adopted by Lakoff and he elaborates its definition of grammatical rules and ideas related to solidarity. Lakoff provides two pragmatic competence rules: (1) Make it clear (referring to Grice's maxims) and (2) Make it polite. To act the second rule, Lakoff (1973:292-305) gives three norms: (a) Do not impose, (b) Give options, (c) Behave.

The conversational maxim view is based on PP as well (Shahrokhi and Bidabadi, 2013:1727). In his PP, Leech $(2015,206-207)$ proposes six maxims to analyze the speaker's politeness: tact maxim, generosity maxim, approbation maxim, modesty maxim, agreement maxim, and sympathy maxim.

It can be concluded from the explanation above that the utterances of speaker and the hearer can be regarded as polite if obeying maxims proposed by PP, either maxims by Grice, Leech, or Lakoff.

\section{(c) Face-saving View}

The face-saving view oriented is based on the concepts of linguistic politeness by Goffman and Brown and Levinson. Goffman (1967:5) holds an opinion:

"Each individual living in a society interacts to each other based on their own function and role. If they want to establish a harmonious social interaction, they have to respect other people's rights in the same way they respect their own." 
Goffman's view indicates that face is a social attribute. However, Brown and Levinson argue that face is a private attribute that has to be considered as well during communication.

Therefore, related to this view, it can be stated that the indicator of linguistic politeness is in the fulfillment of the face's desire. If the face's desire, either it is positive or negative can be fulfilled, the utterance will be valued as polite and the speaker is regarded to be polite.

\section{(d) The Conversational Contract View}

Shahrokhi (2013:17-27) states that linguistic politeness in the conversational contract view follows the politeness concept by Fraser that focuses on rights and obligations of the speaker while communicating. In communication, there are always possibilities provided for both the speaker and the hearer to renegotiate their rights and obligations that have been existed from the beginning of the communication (cf. Rahardi, 2005:38-40).

The indicator of linguistic politeness in conversational contract view is in the rights and obligations of both the speakers and hearers negotiated during the conversation. As long as the speaker and the hearer possess rights to express their utterances based on the happening condition, then the conversation can be regarded as polite and both parties are classified as being polite to each other.

\section{METHODS}

This research was conducted at MAN Model Gorontalo, at X Ekselen class during the subjects of English and Physics were taught, XI Ekselen class during the subjects of Morals, English, Biology, and Physics; XII B1 class during the subjects of Biology, Fiqh, Physics, and Civics; and XII B2 class during the subject of Civics.

Research data were in forms of utterances uttered by teachers and students. The data were collected by hiring the uninvolved conversation observation technique accompanied by data recording (Mahsun, 2012:92-93) and analyzed using the qualitative technique with the stages as follows: (1) Data transcribing, (2) Data collecting, (4) Data discussing, and (5) Conclusion drawing.

\section{FINDINGS AND DISCUSSION}

\section{A. Research Findings}

\section{Politeness Form of Diction Use}

Experts argue various theories on diction (Brooks and Warren, 1950:335; Pranowo, 2012:16; Keraf, 1996:24; Kridalaksana, 2008:50; Arifin \& S. Amran Tasai, 2010:28). Yet among those various theories, the experts suggest a similar argument that diction is a selection of good and correct words employed to convey ideas to others. There are three categories of diction: (1) Pronouns, (2) Addressing terms, and (3) Positive responses (Saleh, 2009).

\section{(a) Pronoun Use}

Based on the research result, the pronouns saya (I), kami (we, the speakers only), kita (we, both the speaker and the hearer), and mereka (they) are included in varieties of formal language with a broad use. Those four terms can be used in an either formal or informal situation. The utterance direction is from teachers to students, students to teachers, and students to other students. The broad scope of pronoun use indicates that the pronouns possess a high level of politeness.

Pronouns whose level of politeness is under those four pronouns are kau (you, for addressing person/people with the same or lower status), anda (you, for addressing person/people with a higher status, and dia (he, she, or it). These three pronouns are within varieties of formal language but the scope of use is limited. Those three pronouns might be hired in a formal situation yet the utterance direction is started from the elder to the younger. If the direction is reversed, then the terms turn to be impolite. The pronouns kau/kamu/anda, kalian (you) and dia (he/she/it) have a lower level of politeness than the pronouns saya (I), kami/kita (we), and mereka (they) because they have more polite synonyms. The polite synonym of the pronoun kau (you) is saudara (mr./miss/mrs.); the polite 
synonims for anda/kamu/kalian (you) are bapak/ibu or saudara-saudara (mr./miss/mrs), and the polite synonims of dia (he/she/it) is beliau (he/she/it but in Indonesian, beliau has a higher status than dia).

Pronouns with the lowest level of politeness are those whose origin are from foreign and local languages. Pronouns belonging to this category are pronouns from the variety of informal languages within a limited use of scope. The examples include kita, ngana, torang, dorang, ngoni; all of which are from local language, plus ana and you. Clearer explanation is provided by Figure 1.

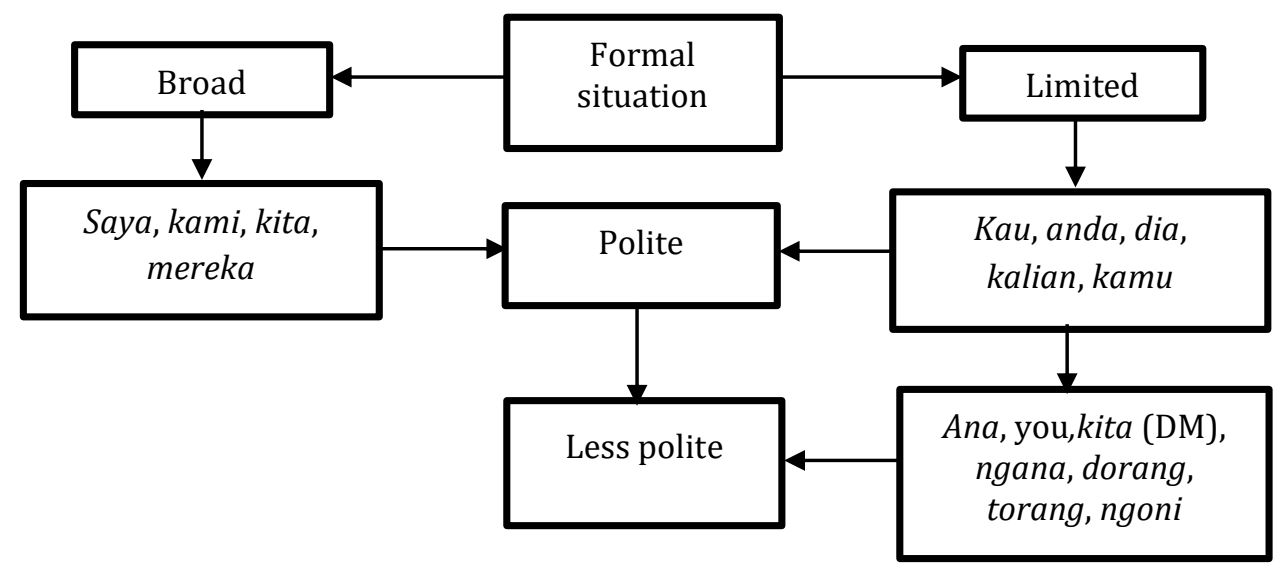

\section{Figure 1: Utterances by Teachers to Students}

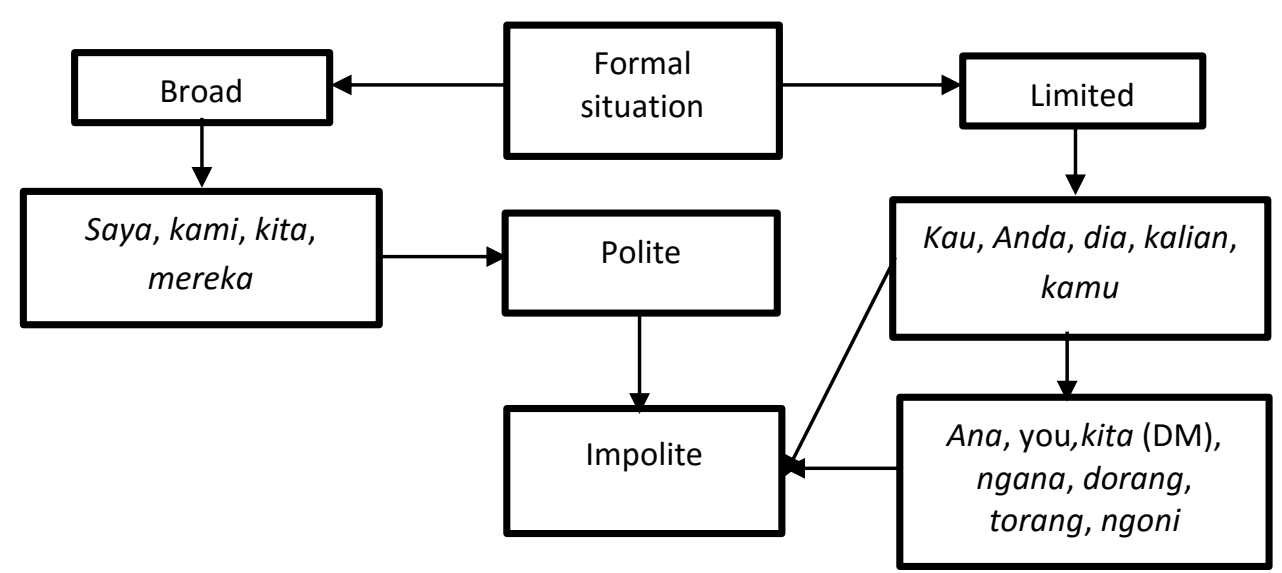

Figure 2: Utterances by Teachers to Students

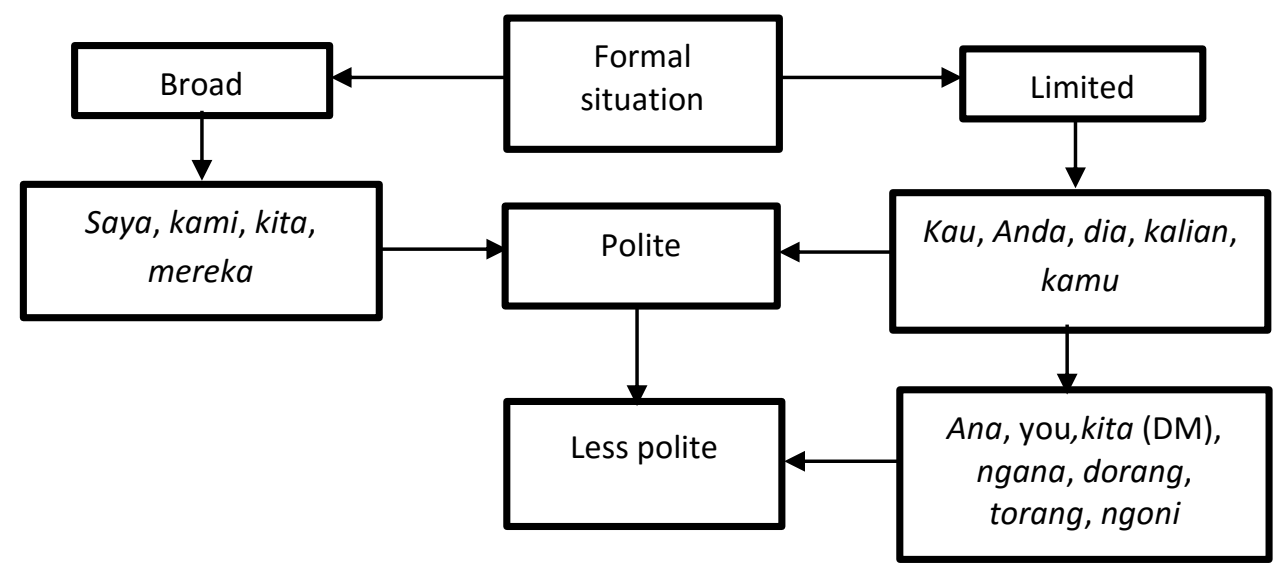

Figure 3: Utterances by Teachers to Students 


\section{(b) Addressing Term Use}

Recent data shows that addressing terms of self-names are either polite or impolite. Addressing terms of kinship, profession, name, and greeting terms are polite. The politeness can be analyzed by measuringthe social distance among the speaker, the hearer, and the context used. In the use of addressing terms of self-names, there is compatibility between addressing term used with the hearer and the context. Teachers greeted the students by mentioning their names. The addressing terms of self-names used was the formal name that were also used in the formal situation.

In using addressing terms of self-names, teachers mentioned front names not the last/family names. In Gorontalo, calling someone by his/her front names is regarded as more polite than calling someone by his/her last or family names since the last will give impression to mock the hearer's parents (the last name is the parent name). Totally different from the teachers, students occasionally called their friends by their family names. Such act of addressing is impolite due to its potency in raising conflicts.

In addressing terms of kinship terms, students used addressing terms $i b u$, mam (ma'am), and pak (sir) that were more polite. Nevertheless, the level of politeness of the addressing terms $i b u$ and pak is considered higher than the addressing term mam because their context of use is considered broader than the addressing term mam. Such addressing term will sound polite if used in an English class and will sound less polite if not used in an English class. In addition, the use of the addressing terms pak and $i b u$ does not reduce the politeness level of utterance in an either formal or informal situation.

In addressing terms of profession terms, students used the addressing term pak guru. The addressing term is categorized as polite since suiting the profession of the hearer. The use of addressing term of profession is not bounded by the context. Hence, either used duringor not during learning process, the use of the addressing term is still considered as polite if the addressing term matches the profession of the hearer.

In addressing terms of self-names, teachers used the addressing terms no' $u$, пипи, uti, and mbak. Those addressing terms are categorized as polite since suiting the social distance between the speaker and the hearer. The addressing terms no' $u$, nunu, uti, and mbak are bounded to the social distance. The addressing words are polite if used by the elder to the younger that have known each other in an either formal or informal situation. The addressing terms are categorized as less polite if used by the elder to the younger that have not known each other yet especially in a formal situation. If used by the younger to the elder that either have or have not known each other in an either formal or informal situation, then the addressing words will be considered as impolite. Moreover, the addressing words will be regarded as less polite if used by people with the same age that have known each other especially in a formal situation.

In using the addressing terms of greeting terms, either teachers or students used an Arabic greeting term: assalamu'alaikum warahmatullahi wabarakatuh. The greeting term possesses a high level of politeness since not limited by the social distance between either the speaker, the hearer, or the context. In other words, the greeting is universally accepted. The greeting is different from the English greeting good morning. The use of such addressing term is bounded by the situational context that is only during the English class. 


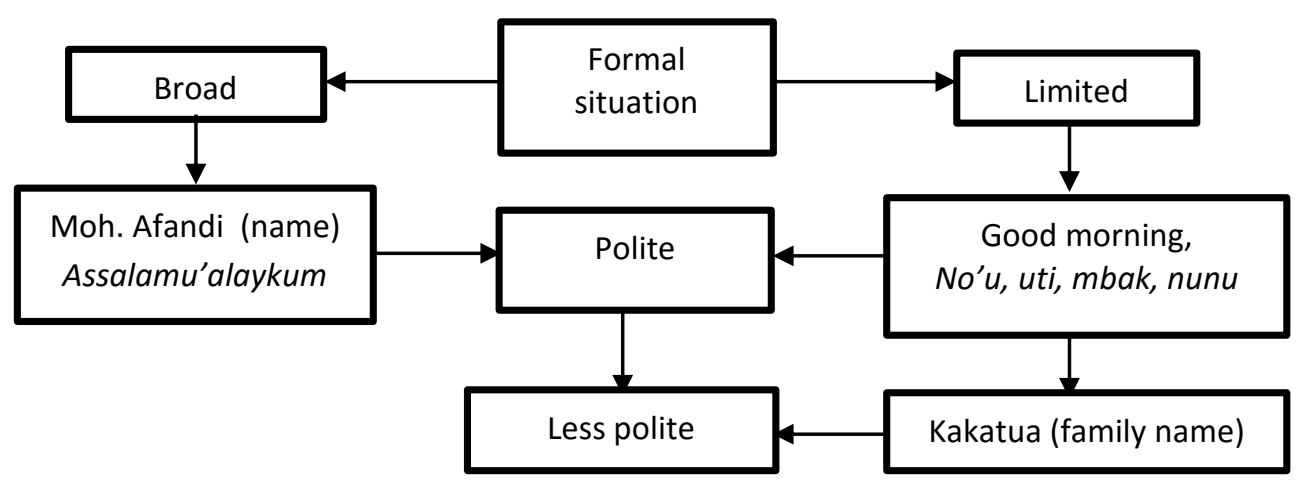

Picture 4: Utterances by Teachers to Students

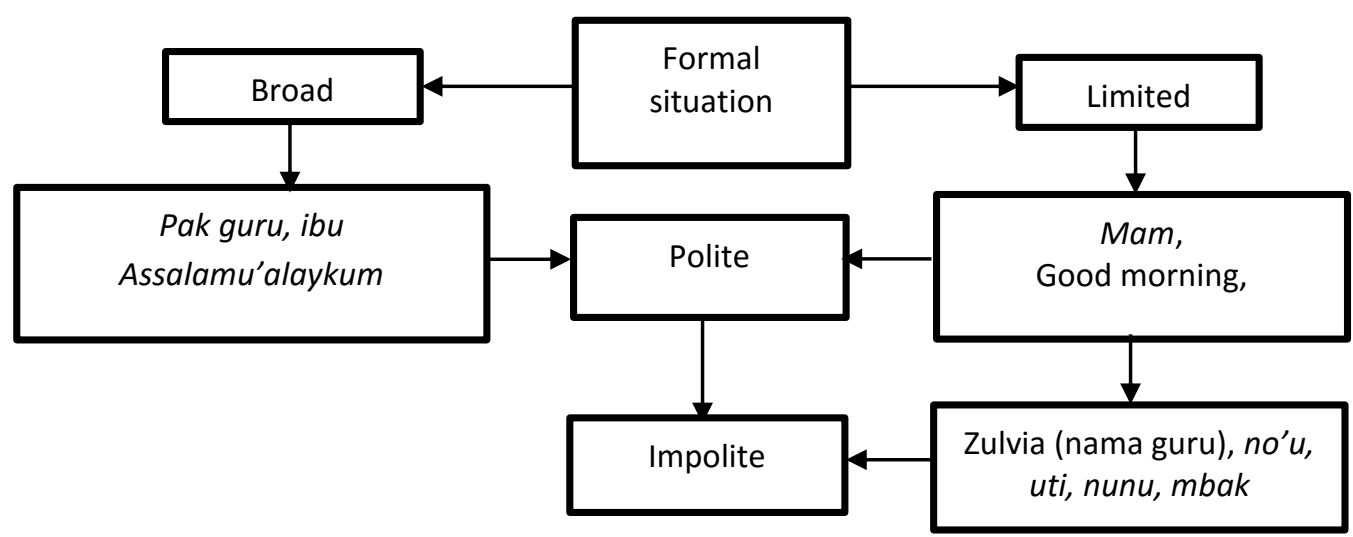

Figure 5: Utterances by Students to Teachers

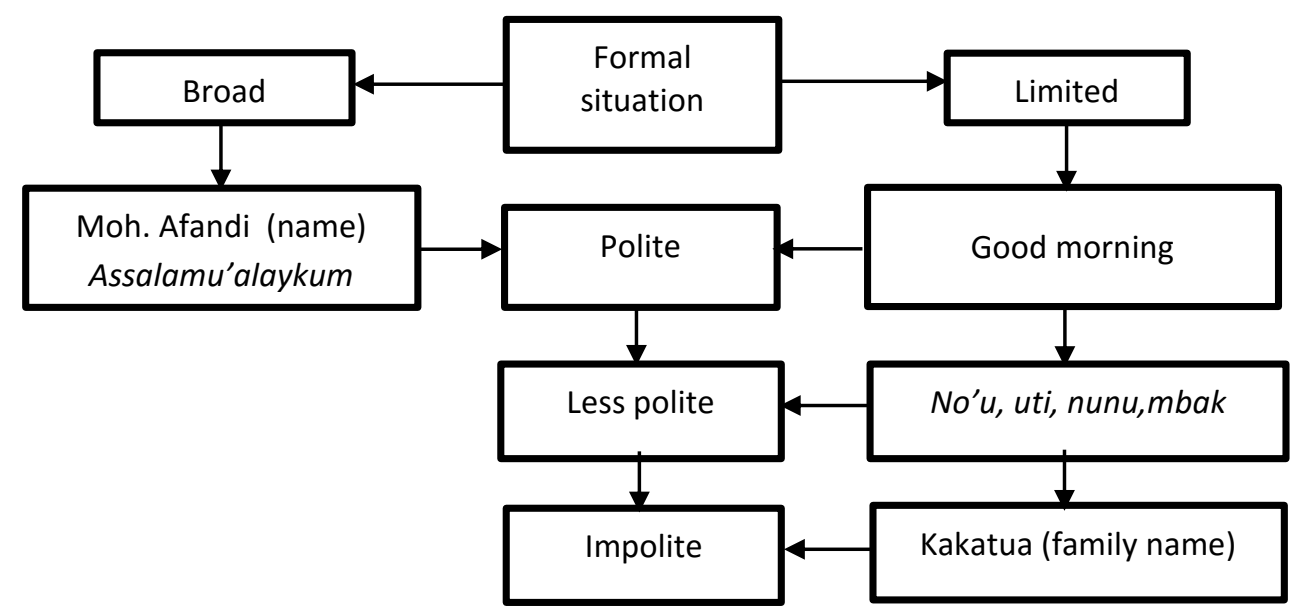

Figure 6: Utterances by Students to Other Students

\section{(c) Positive Response Words}

The data show that diction for positive responses are both polite and impolite. The polite diction consists of the responses ya/iya (yes) and oke (okay); while the impolite one is iyo (yes). The level of polite dictions ya/iya is higher than the dictions oke and iyo. The use of the dictions ya/iya is not bounded by the social distance between the speaker and the hearer and the context. The dictions 
ya/iya can be used by the elder to the younger or by the younger to the elder in an either formal or informal situation.

Furthermore, the use of diction oke is bounded by the social distance between the speaker and the hearer and the context. The diction oke sounds polite if used by the elder to the younger that have known each other in an either formal or informal situation but sounds less polite if used by the elder to the younger that have not known each other yet in a formal situation. Moreover, the diction is categorized as impolite if used by the younger to the elder that have not known each other in a formal situation.

The use of diction iyo is bounded by the social distance among the speaker, the hearer, and the context. The diction iyo is categorized polite if used by the speaker and the hearer that are in the same age that have known each other in an informal context. The diction iyo will sound less polite if used by the elder to the younger that have known each other in an either formal or informal situation. The diction iyo will be impolite if used by the elder to the younger in an either formal or informal situation although both the speaker and the hearer have known each other.

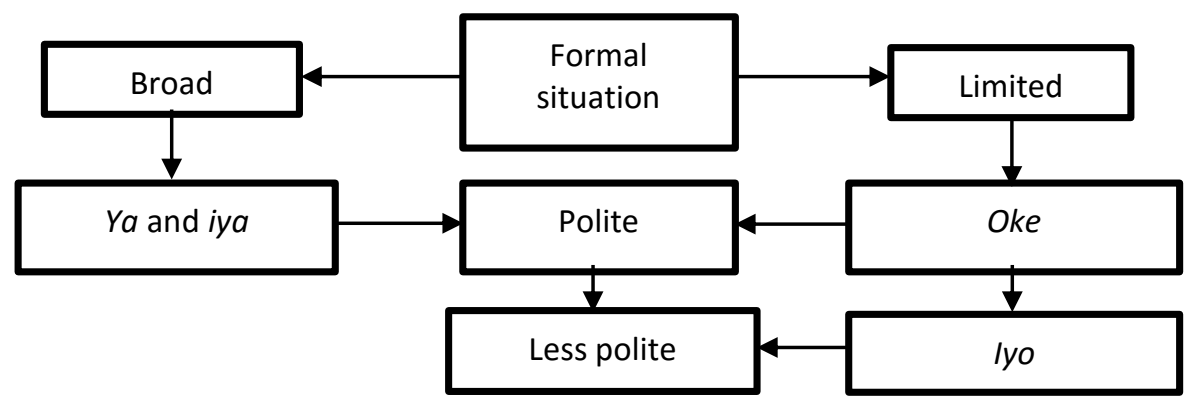

Figure 7: Utterances by Teachers to Students

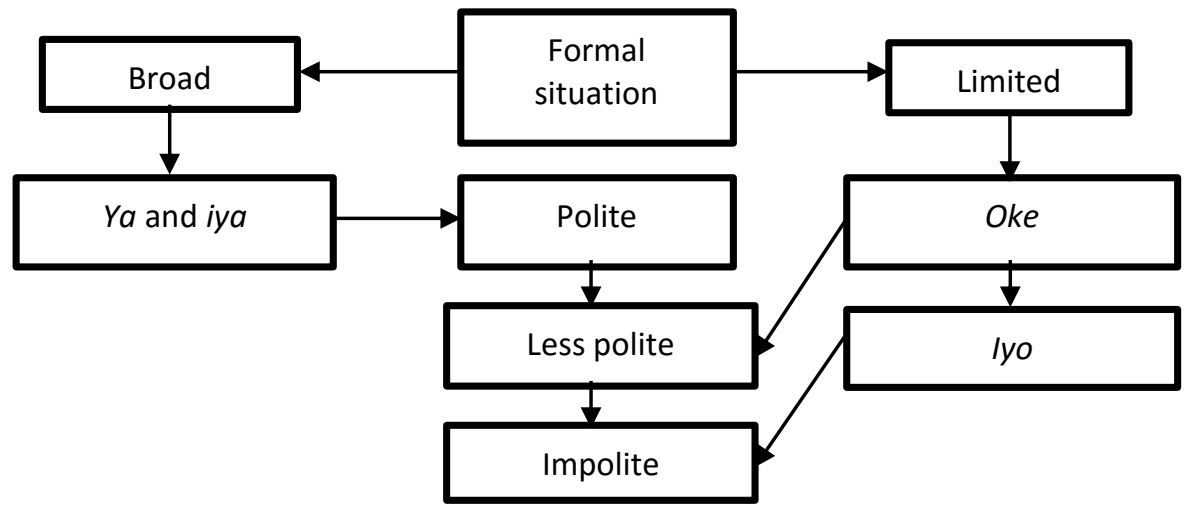

Figure 8: Utterances by Students to Teachers

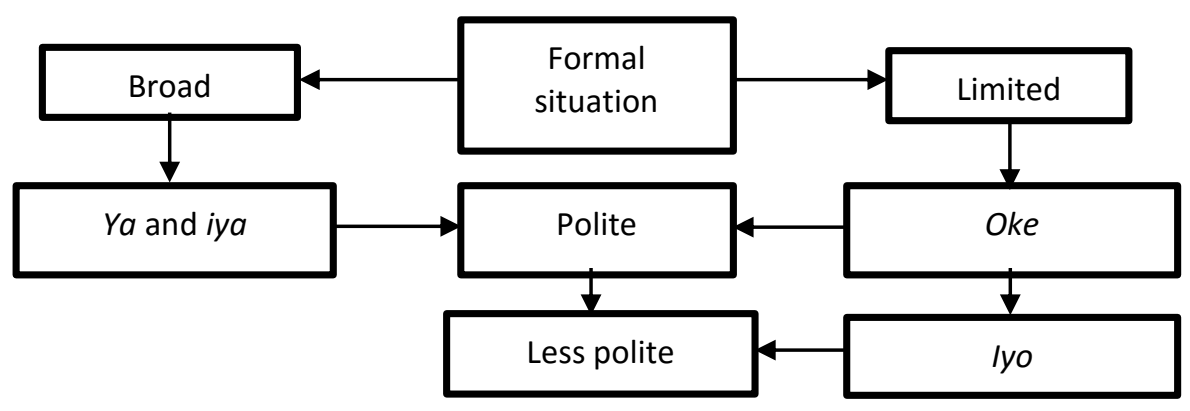

Figure 9: Utterances by Students to Other Students 
The findings suggest that the appropriate diction used during learning process at MAN Model Gorontalo is the universal and formal dictions. Therefore, both universal and formal principles become one of considered principles in linguistic politeness applied during learning process at MAN Model Gorontalo. The universal principle is then formulated in a form of imperative sentences as follows: use more universal dictions during learning process and use less specific dictions during learning process. Formal principles are formulated as follows: use more formal dictions during learning process and use less informal dictions.

\section{Forms of Politeness in Utterance Use}

Lyons (1981:173) differentiates utterances and sentences. Lyons defines sentence as the biggest unit of linguistic description; while utterance is a form or realization of sentence. Sentence is always grammatical; while utterance is not. Sentence is not a physical matter but an abstract idea; while utterance is a physical one since it has a hard or weak sound with different accents from each speaker.

Politeness forms of utterance used during learning process at MAN Model Gorontalo were realized by the uses of declarative, interrogative, and imperative. Politeness forms in those sentential mode were either polite, less polite, or impolite. Such differentiation is caused by obedience and violation of maxims of cooperative and politeness principles.

\section{(a) Declarative Utterances}

Polite and impolite declarative sentences were used by teachers to students. Students used all three types of utterances that were polite, less polite, and impolite. Utterances used by students to other students consisted of less polite and impolite ones. Those politeness forms of declarative utterance by teachers to students, by students to teachers, and by students to other students can be proven by this following excerpt.

Findings of this research suggest that declarative utterances uttered by teachers to students consist of two categories only that are polite and less impolite. The declarative ones uttered by students to other students cannot be regarded as polite. Another finding proposed is that the bigger the distance of both the speaker and the hearer's age is, the more polite the utterance produced is. In the contrary, the closer the distance of the speaker and the hearer's age is, the more impolite the utterance produced is.

\section{(b) Interrogative Utterances}

Interrogative utterances used by teachers to students were either polite or less polite. Interrogative utterances used by students to teachers involved polite, less polite, and impolite utterances. Interrogative utterances used by students to other students consisted of polite, less polite, and impolite utterances. Politeness forms of interrogative utterances by teachers to students, students to teachers, and students to other students are shown by the following excerpt.

The finding suggests that interrogative utterances by teachers to students reach the category of less impolite utterance. Utterances by students to teachers and students to other students only reach the category of impolite utterance. This finding suggests a fact that the age of both the speaker and the hearer does not influence the linguistic impoliteness used.

\section{(c) Imperative Utterances}

Imperative utterances used by teachers to students consisted of both polite and impolite utterances. Imperative utterances used by students to teachers were either polite, less polite, or impolite. The same finding goes to the imperative utterances used by students to other students. Linguistic forms of the above interrogative utterances are shown by this following excerpt.

The finding proposes the fact that imperative utterances by teachers to students reach the category of less polite utterances. Utterances by students to teachers and students to other students reach the impolite level only. The finding thus provides a conclusion that the age of both the speaker and the hearer does not influence the linguistic impoliteness used. 
The types of utterance explained above are uttered either in a direct or indirect way. Utterance uttered in an indirect way is commonly linked to private issues between the speaker and the hearer; while the utterance uttered in a direct way is generally related to classical issues consisting of learning materials. Utterances either indirectly or directly uttered are both polite. Hence, the Politeness Principles by Leech stating that utterances indirectly uttered are more polite than those that are directly uttered is not completely applicable in the learning context. Utterances directly uttered are more understandable in a learning context.

Therefore, the direct principles implemented during learning process are strongly suggested to be a part of linguistic politeness principle. This principle becomes one of linguistic politeness principles applied during learning process, especially at MAN Model Gorontalo. This principle is then formulated in a form of imperative sentences as follows: use more direct utterances in giving learning materials and use less indirect utterances.

\section{RESULT AND DISCUSSION}

As previously mentioned, the research focus is the realization of linguistic politeness during learning process at MAN Model Gorontalo under the sub-focus of the realizations of the forms of diction and utterance uses. The findings are as follows:

\section{Realization of Diction Use}

Brooks and Warren (1950:335-360) divide diction into several types: denotation and connotation, abstract and concrete words, general and specific words, colloquial words, informal and formal words, jargons, and slangs. Formal and informal dictions were found in interactions between teachers and students in class. Formal and informal dictions were realized through the uses of pronouns, greeting terms, and positive response word.

Findings show that the use of pronouns, greeting terms, and positive response are various in their politeness level: polite, less polite, and impolite. Pronouns, greeting terms, and positive response generally categorized as polite is common (the use is not limited by social distance) and formal. The example is as follows:
A [*PTr(12)] : Saya kira cukup, kita akan masuk ke qiyas. (I think it is enough, we will go to qiyas)
Context $\quad$ : Fiqh in XII A1 class. The sentence was about the previous lesson and uttered by a teacher to his/her students.
$\mathrm{B}\left[{ }^{*} \mathrm{P} \operatorname{Tr}(12)\right]$ : Kita rasa cukup, torang akan masuk ke qiyas. (I think it is enough, we are going to discuss qiyas)
Context : Fiqh in XII A1 class. The sentence was about the previous lesson and uttered by the teacher to his/her students.

Utterance A is classified as polite since using the pronouns saya and kita. The pronouns are Indonesian in origin with a common use. In other words, the pronouns can be used by the elder to the younger and the younger to the elder in an either formal or informal context. The pronouns kita, mereka, and kami also undergo the same thing. Furthermore, utterance B is not impolite since the words kita and torang originally come from the local language and is inappropriately used in a formal situation, especially if the speaker is younger than the hearer.

Example of the use of addressing terms and positive response words are as follows:

A [*PKt(121)]: Ibu, ada libur semester? (Ma'am, is there any semester holiday?)

Context : Physics in XII A1 class. The sentence was uttered by a student to his/her teacher in the beginning of 
learning process.

B [*PKt(121)] : Tante, ada libur semester? (Ma'am, is there any semester holiday?)

Context $\quad$ : Physics in XII A1 class. The sentence was uttered by a student to his/her teacher in the beginning of learning process.

C [*PKt(126)] : Jadi kalo dia empat orang berarti dia mampu
melahirkan. Yang dihasilkan empat, empat ovum,
iya kan? (Thus, if she is four people then she can
deliver a baby. She produces four, four ova,
doesn't she?).
: Iya. (Yes).
: Biology in XII A1 class. The conversation was
between a teacher and his/her students during
the learning process.
PD
$\begin{array}{ll}\text { Context Jadi kalo dia empat orang berarti dia } \\ \text { mampu melahirkan.Yang dihasilkan }\end{array}$
$\begin{aligned} & \text { Dempat, empat ovum, iya kan? (A) (She can } \\ & \text { deliver a baby if she is four people. She } \\ & \text { produces four, four ova, doesn't she?) } \\ & \text { : Iyo. (Yes). } \\ & \text { : Biology in XII A1 class. The conversation } \\ & \text { was between a teacher and his/her } \\ & \text { students during the learning process. }\end{aligned}$

Utterance $\mathrm{A}$ and $\mathrm{C}$ are categorized as polite; while the utterance $\mathrm{B}$ and $\mathrm{D}$ are categorized as impolite. The politeness level of utterance A uses a common greeting terms that can be used in both formal and informal situations. It is similar to utterance $\mathrm{C}$ since the utterance uses the common positive response word that can be used by the younger to the elder or vice versa. Politeness of utterance $\mathrm{B}$ is caused by the pronoun tante is specific and only used in an informal situation. Utterance $\mathrm{D}$ is impolite since using the informal positive response word and the fact that the speaker is young.

The variance of politeness mentioned above can be observed through a social distance scale. Social distance scale (Leech, 1983, 2011) states that the further the social distance between the speaker and the hearer is, the more polite the utterance used is. On the contrary, the shorter the social distance between the speaker and the hearer is, the more impolite the utterance is produced. However, referring to the findings stating that universal and formal words are more polite than specific and informal words, the existence of universality and formality scales in communication whose context is formal and number of speakers are various needs to be considered. The more universal diction used in communication is, the more polite the communication is. In the contrary, the more specific the diction used in communication is, the more impolite the communication is. The more formal the diction used in communication is, the more polite the communication is; while the more informal the diction used in communication is, the more impolite the communication is.

The universality and formality scale formulated above is accordance with the context of communication phenomenon formulated by Hymes (1990) widely known as SPEAKING. SPEAKING is actually an acronym of eight contexts of communication phenomena: (1) setting and scene, (2) participants, (3) ends, (4) act sequences, (5) key, (6) instrumentalities, (7) norms of interaction and interpretation, and (8) genres.By focusing on the SPEAKING concept, both the speaker and the hearer can avoid impolite language using. 


\section{Realization of Utterance Use}

Speech act consists of three acts: locution, illocution, and perlocution (Levinson, 1984:236; Rahardi, 2005:35; Wijana, 1996:17). Levinson (1984:236) argues that locution is the speech act with the exact referential meaning; illocution is the speech act in forms of statements, offering, promises, etc. spoken in a form of sentence based on the relevant convention strength; while perlocution is the effect given by the meaning of speech to the audiences.

Based on its functions, utterance can be divided into three: (a) declarative utterance, (b) interrogative utterance, and (c) imperative utterance (Ramlan, 2005:26); Arifin and S. Amran Tasai, 2010:94). Declarative utterance is an utterance containing a statement; interrogative utterance is an utterance containing a question; while imperative utterance is an utterance containing a command.

Leech $(1983,2015)$ states that an utterance is polite if fulfilling one of six maxims of communication. The measure of politeness can be observed through the indirectness scale that contains principles stating that the more direct an utterance is, the more impolite it is; whereas the more indirect an utterance is, the more polite it is.

The statement can only be applied in an informal context with a limited communication participants, a speaker and a hearer or intrapersonal. In a formal situation with a great number of speakers with their various characters, the statement cannot be applied since causing impoliteness. See example below.

\section{$\mathrm{A}[* \mathrm{P} \operatorname{Tr}(52)]$ : Kerjakan halaman 468 nomor 8, dan 10! (Do page 468 number 8 and 10.) \\ Context $\quad$ : Physics in X Ekselen class.}

Leech's politeness scale will categorize the above utterance to be impolite since it is directly spoken and contains a command. Leech builds the idea since he believes that a direct command is impolite due to the fact that it violates the generosity maxim. A direct utterance can make the hearer suffer. However, if the utterance is altered to be an indirect utterance, the teacher will seem being afraid or hesitating in conveying his/her intention to students. The xample is provided below.
$\mathrm{B}[* \operatorname{PTr}(52)]$ : Dapatkah Anda mengerjakan soal pada halaman 468 nomor 8, dan 10? atau saya sangat berterima kasih jika Anda bersedia mengerjakan soal pada halaman 468 nomor 8 dan 10. (Could you please do problems number 8 and 10 on page 468 ? or I would be grateful if you are willing to do problems number 8 and 10 on page 468).

The alteration causes a negative effect for students because it seems that students are given two options: answering yes that means they do what their teacher asked and answering no that means they will not do it. Learning objectives will not be achieved if the students prefer to answer no. Within this context, communication between the teacher and students are achieved but the teacher's intention in making communication does not succeed. Hence, a direct utterance is more suitable to use than the indirect one if the message wanted to convey contains the learning materials.

The statements are in accordance with the cooperative principles by Grice (1967), especially the maxim of manner: avoid obscurity of expression, avoid ambiguity, be brief, and be orderly and with the politeness strategy by Brown and Levinson (1987), especially the bald on record strategy or being honest in utterance.

Referring to the findings, then the indirectness scale by Leech $(1983,2015)$ is only suitable if conducted in an informal situation by participants consisting of one speaker and one hearer or interpersonal. For a formal situation with participants consisting of one speaker and many hearers, 
the relevant impoliteness scale is the directness scale stating that the more the utterances being conveyed are, the more polite they are and the more indirect an utterance is, the more impolite it is.

\section{CONCLUSION}

Based on research results and findings, the researcher concludes that the relevant principles of linguistic politeness used during learning process at MAN Gorontalo consists of three principles: universal, formal, and direct. The universal and formal principles are proven by the realization of diction use (pronouns, addressing terms, and positive response word); while the direct principle is proven by the realization of utterance use.

\section{REFERENCES}

Abdurrahman, Mulyono. 2012. Anak Berkesulitan Belajar: Teori, Diagnosis, dan Remediasinya. Jakarta: Rineka Cipta.

Alhindawi, Fareed H dan Musaab A. Raheem Alkhazaali. 2016. "A Critique of Politeness Theories". Jurnal Theory and Practice in Language Studies, Vol. 6, No. 8. 2016.

Arifin, Zaenal \& S. Amran Tasai. 2016. Cermat Berbahasa Indonesia di perguruan Tinggi. Jakarta: Akademika Pressindo

Bills, Liz. 2000. Politeness in Teacher-Student Dialogue in Mathematics: a Socio-Linguistic Analysis. FLM Publishing Association, Kingston, Ontario, Canada.

Blum-Kulka, Shoshana. 1992. "The Metapragmatics of Politeness in Israeli Society" dalam Richards Watts, S. Ide, K. Ehlich (eds.) Politeness in Language: Studies in its History Theory, and Practice. Berlin: Mounton de Gruyter.

Brown, Penelope and Stephen C. Levinson. 1987. Politeness: Some Universals in Language Usage. New York: Cambridge University Press.

Brooks, Cleanth \& Robert Penn Warren. 1950. Findamentals of Good Writing: A Handbook of Modern Rhetoric. New York: Harcourt, Brace and Company.

Chaer, Abdul. 2010. Kesantunan Berbahasa. Jakarta: PT Rineka Cipta.

Fraser, Bruce. 1990. "Perspective on Politeness. Journal of Pragmatics 14.B. North-Holland

Goffman, Erving. 1967. Interaction Ritual. New York: Anchor Books

Grice, H. Paul. 1975.'Logic and Conversation", in Peter Cole and Jerry Morgan (eds), Syntax and Semantics, vol. 3: Speech Acts. New York: Academic Press.

Gu, Yueguo. 1990. "Politeness Phenomena in Modern Chinese”, Jurnal of Pragmatics 14:237-257.

Held, G. 1992. "Politeness in Linguitic Research" in Politeness in Language: Studies in its History, theory and Practice, edited by R. Watts, S.Ide, \& K. Ehlich. Berlin: Mount De Gruyter

Hymes, Dell. 1990. "Towards Ethnographies of Communication: The Analysis of Communicative Events" dalam Language and Social Context Editor Pier Paolo Giglioli. England: Penguin Books.

Ide, Sachiko. 1989. "Formal Form and Discernment: Two Neglected Aspects of Universal of Linguistic Politeness". Multilingua 8.

Jumanto. 2017. Pragmatik Edisi 2: Dunia Linguistik Tak Selebar Daun Kelor. Yogyakarta: Morfalingua 
Keraf, Gorys. Komposisi. Flores: Nusa Indah

Kridalaksana, Harimurti. 2008. Kamus Linguistik. Jakarta: PT Gramedia Pustaka Utama

Lakoff, R. 1973. The logic of Politeness; or minding your p's and q's. Pp. 292-305 in $9^{\text {th }}$ Regional Meeting of the Chicago Linguistic Society. Chicago: Chicago Linguistic Society.

Leech, Geoffrey. 2011. Prinsip-Prinsip Pragmatik Terjemahan M.D.D. Oka. Jakarta: UI Press.

Leech, Geoffrey. 1983. Principles of Pragmatics. New York: Longman.

Liu Peng, et.al. 2014. “A Case Study of College Teacher's Politeness Strategy in EFL Classroom”. Theory and Practice in Language Studies, Vol. 4, No. 1. ACADEMY PUBLISHER Manufactured in Finland.

Lyons. 1981. Introduction to Theoretical Linguistic. London: Cambridge University Press.

Mahsun. 2012. Metode Penelitian Bahasa. Jakarta: Raja Grafindo Persada.

Pramujiono, Agung. 2011. "Refresentasi Kesantunan Brown \& Levinson dalam Wacana Dialog Televisi”, Prosiding, Kongres Internasional Masyarakat Linguitik Indonesia, Jakarta: Universitas Atmajaya.

Pranowo. 2012. Berbahasa Secara Santun. Yogyakarta: Pustaka Pelajar.

Rahardi, Kunjana. 2005. Pragmatik: Kesantunan Imperatif Bahasa Indonesia. Jakarta: Erlangga.

Saleh, Muhammad. 2009. "Representasi Kesantunan Berbahasa Mahasiswa dalam Wacana Akademik: Kajian Etnografi Komunikasi di Kampus Universitas Negeri Makassar". Unpublished dissertation.

Shahrokhi, Mohsen dan Farinaz Shirani Bidabadi. 2013. An Overview of Politeness Theories: Current Status, Future Orientations. American Journal of Linguistic 2013, 2 (2).

Spencer-Oatey, H. 1992. Cross-Cultural Politeness: British and Chinese Conception of the TutorStudent Relationship (Unpublished PhD Thesis) Lancaster University.

Spencer-Oatey, H. 2000. Raport Managemen: A Framework for Analysis in Culturally Speaking: Mananging Raport through Talk across Cultures, edited by H Spencer-Oatey. London: Continum.

Wijana, I Dewa. 1996. Dasar-Dasar Pragmatik. Yogyakarta: Andi Offset.

Wijayanto, Agus, et.al. 2013. "Politeness in Interlanguage Pragmatics of Complaints by Indonesian Learners of English. English Language Teaching; Vol. 6, No. 10. Published by Canadian Center of Science and Education.

Yule, George. 2006. Pragmatik (translated by Indah Fajar Wahyuni). Yogyakarta: Pustaka Pelajar. 